NAMA $\quad$ : RISKAYANTI.M

NIM $\quad: 90100118027$

TUGAS $\quad$ :SEJARAH PEMIKIRAN EKONOMI ISLAM

\title{
KONSEP EKONOMI PADA MASA KHULAFAUR RASYIDIN
}

Khulafaur Rasyidin berasal dari kata khulafa' dan al-rasyidin, kata khulafa' yaitu cerdik, pandai dan pengganti. kata al-rasyidin yaitu lurus, benar dan mendapat petunjuk. Jadi Khulafaur Rasyidin merupakan orang-orang cerdik yang baik dan benar yang dipilih sebagai pemimpin pengganti Rasulullah Shallallahu Alaihi Wasallam setelah beliau wafat. Para pemimpin Khulafaur Rasyidin terdiri dari empat orang sahabat Rasulullah, yaitu : Abu Bakar ash-Shiddiq, Umar bin Khatab, Utsman bin Affan dan Ali bin Abi Thalib.

1. Masa Abu Bakar ash-Shidiq

Usaha dalam meningkatkan kesejahteraan ummat, Abu Bakar ash-Shidiq melaksanakan berbagai kebijakan ekonomi yang telah dilakukan oleh Rasulullah Shalllahu Aalaihi Wasallam. Berikut langkah-langkah yang dilakukan oleh Khalifah Abu Bakar ash-Shidiq

a) keakuratan perhitungan zakat sangat diperhatikan.

b) Pengembangan terhadap pembangunan Baitulmal dan penanggung jawab atas Baitulmal.

c) Menerapkan konsep balance budget pada Baitulmal.

d) Memerangi kaum murtad, nabui palsu dan orang yang tidak mau membayar zakat.

2. Pada Masa Umar bin Khatab

Kebijakan khalifah Umar bin Khattab pada masa beliau menjadi pemimpin:

a) Reorganisasi baitulmal, dimana menjadikan baitulmal sebagai lembaga negara yang resmi dikenal dengan nama al-diwan 
b) Diberlakukannya sistem cadaanfan darurat, dimana dari sumber penerimaan yang ada tidak langsunng di distribusikan seluruhnya. Hal ini untuk membiayai angkatan perang dan kebutuhan darurat untuk ummat.

c) Pemerintah bertanggung jawab terhadap pemenuhan kebutuhan minum, makanm dan pakaian kepada warga negaranya.

d) Diverifikasi terhadap objek zakat, dimana dilakukan objek yang dapat dikenankan sebagai objek zakat yang baru. Dalam bahasa fiskal saat ini biasa dikenal dengan eksentifikasi sumber-sumber penerimaan negara.

e) Pengembangan $u s h r$ (pajak) pertanian.

f) Undang-undang perubahan pemilikan tanah, dimana tanah tidak produktif dikuasai oleh negara untuk diolah masyarakat dan masyarakat membayarkan pajak atas tanah yang dikelolah tersebut.

3. Pada Masa Ali bin Abi Thalib

Masa pemerintahan Umar bin Abi Thalib berlangsung selama 5 tahun. Kebijakan ekonomi Ali bin Abi Thalib diantaranya yaitu :

a) Melakukan pemertaan

b) Menetapkan pajak terhadap para pemilik kebun dan mengijinkan pemungutan zakat terhadap sayuran segar.

c) Pembayaran gaji secara mingguan

d) Melakukan control pasar dan pemberantas pedagang licik, penimbun barang dan pasar gelap.

e) diberlakukannya aturan konpensasi bagi para pekerja jika mereka merusak barang-barang pekerjaannya. 


\section{DAFTAR PUSTAKA}

Ahmad Al-Hadits, Jariabah bin, Fikih Ekonomi Umar bin Al-Khattab, Jakarta:KHALIFA, 2006.

Karim, Adiwarman, Sejarah Pemikiran Ekonomi Islam, Jakarta:PT.Pustaka Penerbit, 2002. 